\title{
SCIENCE EDUCATION - A NEW VISION AND MISSION
}

\section{Ronald Mascarenhas*}

Science education in schools and colleges across the country is facing a crisis. Science is regarded as not only difficult but also alien, irrelevant and boring. This is quite evident by the declining enrolment in science at the college level. Added to this with the opening up of the economy, there is a greater demand for business administrators and computer-literate individuals. There is also this notion that career opportunities in engineering and medical field are more lucrative. Consequently, pursuit of science is the last priority of students. I would like to discuss this problem under two heads.

\section{Curriculum}

Science teaching in our country at the school level is characterized by almost complete absence of experimentation by the children in the classroom. Science is taught in the school as a body of finished knowledge, as a discipline that is complete. No questions are ever raised in the science curriculum whose answers are not known. The students are prevented from ever suspecting that anything in the scientific world still remains to be fully understood.

The way science is taught in school does not place the child at the centre of the things. School science seems to be artificial and does not emerge from the daily lives of children. Children's natural curiosity about the world around is not built

* St. Agnes College, Mangalore 
upon and often even actively suppressed. The actual process of science observation, experimentation, analysis, investigation and framing and testing hypothesis find no place in the mainstream curriculum.

Science teaching is mainly driven by the logic of discipline. Principles take precedence over practice; the products are given more importance than the process of science. Students graduate with lot of information but with very little ability to apply the knowledge to problem solving situations which affect them, the society and the environment.

I would like to emphasize, learning of science should go hand in hand with the process of science. Students should be exposed to observe the world around them, go on field trips, do laboratory experiments, undertake investigative projects, analyse, discuss, argue and make mistakes and learn. These things have to be introduced at the school level and sustained and promoted in depth at the college level. Though there are attempts to include many experiments in the textbooks in the recent curriculum, there is no proper time in the schedule nor an attempt to provide equipment to perform them in the classroom.

It is important that the teaching of science takes a paradigm shiff from teaching to experimenting, from learning to experiencing. Students should be encouraged to discuss questions that are relevant to the society and environment.

- Should we or should we not divert the rivers?

- Should we use nuclear energy to generate electricity?

- Should we use chemical fertilizers and insecticides?

- Should we go for genetically modified plants?

- Cloning - boon or bane?

- Should we dig borewells and pump water for irrigation at the risk of depleting our ground water resources? etc.

Decimation of the Science Education should start with real life problems.

- Why there are growing cases of malaria in the town?

- Why there are many power cuts?

- Why are most wells gone dry?

- Why there are increasing cases of cancer etc.? 
Science education should address the need of overall development of students who can

- Update knowledge independently

- Utilise acquired knowledge in problem solving

- Communicate knowledge effectively

- Think rationally

- Reflect and form opinions.

- Work in multidisciplinary teams

- Utilise information technology effectively.

\section{Role of Teachers}

Teaching has many facets to it. Possessing a good academic record is not an essential attribute for a good teacher. Above average intelligence has to be combined with effective communication skills.

Equally important is for a good teacher unlimited patience, abundant energy and enthusiasm. Teachers who reveal unbounded enthusiasm for their work can always inspire their students to learn.

Student's performance is directly linked with teacher's expectations. Where the teacher's expectations are clear, students will fulfill those expectations. High expectations lead to high performance.

A teacher should be excited about the subject which in turn creates excitement among the students. Teachers primarily should encourage the students to think. In the rush of trying to get through the curriculum teachers rarely provide opportunities for the students to do the thinking. They only provide information and knowledge. Starting a class with a relevant question and allowing some time for student response and interaction would really help in sharpening their brains.

"Tell me, I forget; Show me, I remember; Involve me, I understand"

Involving the students in the demonstration and explanation of the experiments connected to the subject will help to enthuse interest and keep a receptive mood in the class. 
A teacher should encourage the students to ask questions. Many a times the questions of students are intelligent and embarrassing (because we do not know the answer). A teacher should consider the question to which he does not know the answer as most thought-provoking.

Project work, which is an important element of science teaching is meant to develop scientific temper and scholarliness in students. Teachers must play an active role as guides to the students to discover facts for themselves through investigation, observation, analysis, recording etc.

Out-reach or extension activities should also be encouraged by the teachers. Knowledge as well as use of the knowledge to serve the community should become an integral part of science teaching.

Many great scientists owe their success to their teachers. Teachers should kindle a thirst for scientific knowledge among the students and the knowledge should always be directed towards the betterment of the community.

It is said

A poor teacher complains

An average teacher explains

A good teacher teaches

A great teacher inspires

Teachers have a great role in science education to make the learning of science interesting effective and socially relevant. 